\title{
Pembelajaran IPS dengan Strategi Pemecahan Masalah untuk Meningkatkan Kemandirian dan Kepedulian Siswa
}

\author{
RARAS GISTHA ROSARDI \\ Jurusan Pendidikan IPS FIS Universitas Negeri Yogyakarta \\ e-mail: rarasrosardi@ymail.com
}

\begin{abstract}
Abstrak
Penelitian ini bertujuan 1) Menguji perbedaan yang siginifikan pada hasil belajar kognitif, kemandirian dan kepedulian antara siswa; 2) Menguji keefektifan strategi Pemecahan Masalah untuk meningkatkan hasil belajar kognitif, kemandirian dan kepedulian siswa. Penelitian ini merupakan penelitian kuasi eksperimen. Populasi penelitian ini adalah semua siswa SMP Muhammadiyah 2 Depok, Sleman DIY. Sampel ditentukan dengan teknik random sampling untuk menentukan kelas eksperimen dan kelas kontrol. Data yang terkumpul dianalisis dengan statistik Multivariate Analysis of Variance (MANOVA) pada $\alpha=0,05$. Hasil penelitian menunjukkan bahwa Strategi pembelajaran Pemecahan Masalah dan strategi pembelajaran Konvensional: 1) menunjukkan perbedaan hasil belajar kognitif, kemandirian dan kepedulian secara bersama-sama. 2) menunjukkan perbedaan terhadap hasil belajar kognitif. 3) menunjukkan perbedaan terhadap nilai kemandirian. 4) menunjukkan perbedaan terhadap nilai kepedulian.

Kata kunci: strategi pembelajaran pemecahan masalah, hasil belajar kognitif, kemandirian, kepedulian
\end{abstract}

\begin{abstract}
This study aims to test the significant difference of cognitive learning outcomes, self-reliance and care among students who take social studies learning and problem solving strategies of students who take social studies learning which uses Conventional learning and test the effectiveness of problem solving strategies to improve cognitive learning outcomes, self-reliance and student's concern. This research is a quasi- experimental study. The population in this study was all students of SMP Muhammadiyah 2 Depok, Sleman DIY. The samples was determined by random sampling technique to determine the experimental class and the control class. The data were analyzed using Statistical Multivariate Analysis of Variance (MANO VA) at $\alpha=0.05$. The results of the study are as follows: 1 ) the use of problem solving and Conventional learning strategies show differences in cognitive learning outcomes, self-reliance and care, 2 ) Problem Solving and Conventional learning strategies show differences in the cognitive learning outcomes, 3 ) Problem Solving and Conventional learning strategies show differences in the value of autonomy and 4) Problem Solving and Conventional learning strategies show differences in the value of care.
\end{abstract}

Keywords : Problem learning strategies, learning outcomes koginitif, self-reliance, care 


\section{PENDAHULUAN}

Kebijakan pemerintah terkait dengan pendidikan karakter merupakan langkah baik untuk membenahi sistem pendidikan di Indonesia. Kebijakan Nasional Pembangunan Karakter Bangsa Tahun 2010-2025 telah dicanangkan oleh pemerintah sebagai wujud dari solusi untuk melakukan reformasi pendidikan ke arah yang lebih humanis dan bermakna. "Ruang lingkup sasaran pembangunan karakter bangsa antara lain: keluarga, satuan pendidikan, pemerintah, masyarakat sipil, masyarakat politik, dunia usaha dan industri, serta media massa" (Darmiyati Zuchdi, 2011:15).

Pembangunan karakter bangsa melibatkan beberapa elemen kehidupan. Pendekatan secara holistik dan komprehensif sangat diperlukan untuk mewujudkan kesuksesan pendidikan karakter dalam segala elemen kehidupan. Akan tetapi hal ini kurang di sadari oleh sebagian besar masyarakat dan pemangku kebijakan. Kondisi yang terjadi adalah semakin banyak kasus ketidakadilan hukum, kekerasan dalam lingkungan pendidikan, konflik keluarga, kekerasan antar suku, ras, agama dan keyakinan Ketuhanan, plagiat karya ilmiah, menyontek massal saat Ujian Nasional dan lain-lain.

Dalam ruang lingkup satuan pendidikan dasar dan menengah, Badan Penelitian dan Pengembangan, Pusat Kurikulum Kementerian Pendidikan Nasional (2011:8) telah memilih nilai-nilai materi pendidikan karakter yang perlu dikembangkan yaitu: religius, jujur, toleran, disiplin, kerja keras, kreatif, mandiri, demokratis, rasa ingin tahu, sema ngat kebangsaan, cinta tanah air, menghargai prestasi, bersahabat dan komunikatif, cinta damai, gemar membaca, pedulilingkungan, peduli. Nilaiinidiharapkan mampu menjadi terobosan tersendiri untuk memperbaiki kualitas sumber daya manusia melalui kurikulum. Penguatan jati diri bangsa dengan memahami dan menerapkan nilai-nilai falsafah yang terkandung dalam Pancasila, Undang-Undang Dasar 1945, dan Bhineka Tunggal Ika.

Sistem pendidikan yang mampu mengem- bangkan pribadi yang memiliki karakter terpuji yang secara personal dan sosial siap memasuki dunianya seharusnya menjadi tujuan utama setiap institusi pendidikan (Darmiyati Zuchdi, 2011:1). Hal ini perlu disadari oleh para pemangku kebijakan pendidikan bahwa berhasil atau tidaknya pembangunan karakter bagi masyarakat itu ada di tangan penyelenggara pendidikan. Proses pendidikan yang mengedepankan nilai-nilai humanis akan menghasilkan sumber daya manusia yang berkualitas sesuai dengan jati diri bangsa Indonesia. Akan tetapi para pemangku kepenti ngan dalam pendidikan kurang menyadari sepenuhnya akan hal itu, sehingga proses pendidikan tidak sampai pada penyampaian nilai-nilai moral, etika dan karaker kebangsaan yang semestinya dapat ditunjukkan dengan pemberian contoh, penerapan dalam mata pelajaran dan kegiatan ekstra kurikuler.

Penerapan pendidikan karakter melalui mata pelajaran akan membawa proses perubahan pada kualitas hasil pendidikan itu sendiri. Hal ini didukung oleh pernyataan Darmiyati Zuchdi (2011:3) bahwa dalam mendidik karakter, seorang guru harus memiliki perilaku yang mencerminkan karakter baik yang dimilikinya dan menerapkan dalam strategi pembelajaran tertentu yang dapat mendorong anak untuk mengembangkan karakter. Strategi pembelajaran yang mampu mengembangkan karakter pada peserta didik belum sepenuhnya menjadi prioritas bagi guru. Hal ini dibuktikan dengan masih mendominasinya strategi pembelajaran konvensional yang diterapkan oleh sebagian besar guru di sekolah sehingga pembelajaran menjadi kurang efektif.

Salah satu mata pelajaran yang dapat digunakan untuk mengembangkan pendidikan karakter adalah Ilmu Pengetahuan Sosial (IPS). Berdasarkan Standar Isi Untuk Mata Pelajaran IPS SMP (BSNP, 2006:159), IPS merupakan salah satu mata pelajaran yang diberikan mulai dari SD/MI/SDLB sampai SMP/MTs/SMPLB. IPS mengkaji seperangkat peristiwa, fakta, konsep, dan generalisasi yang berkaitan dengan isu sosial. Pada jenjang SMP/MTs mata pelajaran IPS memuat materi Geografi, Sejarah, Sosiologi, dan Eko- 
nomi. Melalui mata pelajaran IPS, peserta didik diarahkan untuk dapat menjadi warga negara Indonesia yang demokratis, dan bertanggung jawab, serta warga duniayang cinta damai. Peserta didik diharapkan akan memperoleh pemahaman yang lebih luas dan mendalam pada bidang ilmu yang berkaitan. Keterpaduan yang dihadirkan dalam mata pelajaran IPS di SMP mengarahkan peserta didik agar cakap dalam pola pikir dan memiliki keterampilan menganalisis materi pelajaran IPS secara lebih bermakna.

Berdasarkan Bab IV Pasal 19 PP No. 19 Tahun 2005 tentang Standar Nasional Pendidikan, bahwa:

"Proses pembelajaran pada satuan pendidikan diselenggarakan secara interaktif, inspiratif, menyenangkan, menantang, memotivasi peserta didik untuk berpartisipasi aktif, serta memberikan ruang yang cukup bagi prakarsa, kreativitas, dan kemandirian sesuai dengan bakat, minat, dan perkembangan fisik serta psikologis peserta didik. "

Pendidikan karakter mandiri bertujuan untuk mengembangkan insan-insan yang percaya kepada dirinya sendiri dalam mengerjakan sesuatu urusan. Karakter mandiri mendorong dan memacu seseorang untuk memecahkan sendiri persoalan hidup dan kehidupannya, sehingga dia termotivasi untuk berinisiatif, berkreasi, berinovasi, proaktif dan bekerja keras. Seperti yang dikatakan oleh Darmiyati Zuchdi (2010:7), bahwa "pendidikan nilai/moral hendaknya mampu menumbuhkan kemandirian, dengan demikian subjek didik semakin mampu me ngatasi masalah yang dihadapi". Pendidikan budi pekerti mandiri memacu keberanian seseorang untuk berbuat atau bereaksi, tidak pasrah dan pasif, tetap dinamis, energik dan selalu optimis menuju ke masa depan. Selain kemandirian, nilai karakter yang mampu dimunculkan melalu pembelajaran IPS adalah kepedulian. Hal ini didukung oleh pernyataan dari Darmiyati Zuchdi (2011:8) bahwa:

"Dalam mewujudkan karakter individu, diperlukan pengembangan diri secara holistik, yang bersumber pada olah hati, olah pikir, olah raga, dan olah karsa. Sep- erti yang telah dikemukakan dari konfigu rasi nilai yang terdapat dalam ranah olah hati, olah pikir, olah raga, dan olah rasa/ karsa masing-masing diambil satu nilai sebagai nilai-nilai utama karakter yang dikembangkan secara nasional, termasuk dilingkungan Dikti. Karakter yang dimaksud adalah: Jujur, Cerdas, Tangguh, Peduli (Jurdastangli)."

Kepedulian mampu mengarahkan peserta didik untuk memiliki keterampilan sosial yang baik, karena dalam kepedulian terdapat rasa tanggungjawab dan kerjasama antar sesama. Bahkan dikatakan bahwa seorang ilmuwan yang memiliki tanggung jawab sosial harus bersikap objektif, terbuka, menerima kritik, menerima pendapat orang lain, kukuh dalam pendirian dan berani mengakui ke salahan (Darmiyati Zuchdi, 2010:128). Nilai kepedulian memiliki arti penting untuk kepentingan pembawaan diri.

Kesenjangan sosial diakibatkan oleh kondisi masyarakat yang masih dalam kesengsaraan dan penderitaan. Kesengsaraan dan penderitaan akan dapat dihindari apabila manusia memunculkan sifat-sifat mulia ke manusiaannya seperti: welas asih, kedermawanan, kejujuran, kepedulian dan pe ngendalian diri (Gede Raka, 2011:23). Untuk dapat berbuat demikian, disamping kemampuan analisis juga diperlukan integritas kepribadian (Darmiyati Zuchdi, 2010:128). Hal ini sesuai dengan salah satu tujuan IPS adalah memiliki komitmen dan kesadaran terhadap nilai-nilai sosial dan kemanusiaan (BSNP, 2006:159).

Strategi pemecahan masalah merupakan salah satu metode dalam kegiatan pembelajaran dengan jalan melatih siswa menghadapi berbagai masalah baik itu pribadi dan kelompok kemudian dipecahkan baik secara individu atau bersama-sama (Ali Muhson, dkk. , 2008:34). Metode Pemecahan masalah dapat dijadikan sebagai salah satu cara pembaharuan dalam pelaksanaan pembelajaran IPS sehingga akan dirasakan lebih bermakna (meaningful learning). Penelitian yang dilakukan oleh Ali Muhson, dkk (2008:51) menegaskan bahwa penerapan metode problem solving dalam pembelajaran dapat me- 
ningkatkan minat belajar dan pemahaman mahasiswa. Indikasinya adalah proses pembelajaran cukup menyenangkan dan mampu meningkatkan peran aktif serta hasil belajar mahasiswa. Dapat disimpulkan bahwa strategi pemecahan masalah dapat memperbaiki kondisi kelas secara pedagogi dan hasil belajar. Dalam hal ini, peneliti ingin melakukan penerapan strategi pemecahan masalah dalam pembelajaran IPS untuk meningkatkan kemandirian dan kepedulian siswa.

Berdasarkan hasil observasi di SMP Muhammadiyah 2 Depok terdapat beberapa kelemahan dalam pembelajaran IPS yaitu dominasi guru dalam aktivitas kelas masih terlihat sehingga siswa bergantung sepenuhnya dengan guru. Selain itu, guru dalam menyampaikan materi IPS tidak terdapat aspek afektif diberikan kepada siswa sehingga aspek kognitif saja yang ditekankan. Guru kurang mengarahkan siswa untuk menganalisis kondisi lingkungan sekitar yang dikaitkan dengan materi IPS dan pendidikan karakter melalui tugas, kuis, permainan, berdiskusi, presentasi.

\section{Strategi Pemecahan Masalah}

Proses pemecahan masalah melibatkan tiga jenis berpikir yaitu: analisis, kreatif dan kritis. Masalah ini bukan hanya sesuatu yang tidak bekerja dengan baik atau tugas yang guru berikan siswa untuk bekerja keluar, masalah adalah sesuatu yang bisa dibuat berbeda atau lebih baik melalui beberapa perubahan. Proses pemecahan masalah secara kreatif melibatkan ketiga jenis berpikir: ana litis, kreatif dan kritis.

Isaksen, dkk. (2011:19) menyebutkan bahwa:

"problem solving generally involves devising ways to answer question and to meet or satisfy a situation which presents a challenge, offers an opportunity or is a concern".

Berdasarkan pengertian tersebut dapat dipahami bahwa pemecahan masalah pada umumnya melibatkan rancangan cara untuk menjawab pertanyaan dan untuk memenuhi atau menjelaskan suatu situasi yang menyajikan sebuah tantangan, menawarkan peluang atau perhatian.

Problem solving diharapkan mampu menjadi cara untuk menjadikan pembelajaran menjadi lebih bermakna karena terdapat unsur kepekaan atas suatu masalah yang dihardirkan kepada siswa. Dalam hal ini, peran guru adalah membantu siswa untuk mengeks plorasi pengetahuan dan kemampuan analisis sehingga siswa mampu mencapai tahap pemecahan masalah.

Dengan menerapkan strategi pemecahan masalah, maka peserta didik menjadi lebih dekat dengan kehidupan nyata. Pendapat tersebut didukung oleh Nasution (2006:117) yang menyatakan bahwa:

"Metode problem solving merupakan pemecahan masalah yang dapat dipandang sebagai manipulasi informasi secara sistematis, langkah demi langkah, dengan mengolah informasi yang diperoleh melalui pengamatan untuk mencapai suatu hasil pemikiran sebagai respon terhadap suatu masalah yang dihadapi."

Problem solving membutuhkan kepekaan yang berasal dari kegiatan pengamatan dengan bertujuan untuk mengumpulkan berbagai informasi yang diperlukan sehingga mampu menemukan solusi terhadap masalah yang sedang dibahas. Melalui pro blem solving peserta didik diarahkan untuk berpikir lebih luas dan kontekstual karena dengan memecahkan masalah yang dilaksanakan pada suatu pembelajaran, peserta didik memahami tujuan pembelajaran.

Berdasarkan beberapa uraian tentang pengertian problem solving maka dapat diambil kesimpulan bahwa strategi pembelajaran problem solving adalah strategi pembelajaran yang mengarahkan peserta didik untuk mampu menemukan, menelaah, me nganalisis dan memberikan solusi terhadap suatu masalah yang berkaitan dengan materi dalam proses pembelajaran.

\section{METODE}

Penelitian ini menggunakan eksperimen semu (quasi experiment). Dalam metode eksperimen digunakan dua kelompok subjek penelitian yang terdiri atas kelompok eks- 
perimen dan kelompok kontrol. Kelompok eksperimen diberikan perlakuan dengan strategi pemecahan masalah dan kelompok kotrol diberikan perlakuan dengan strategi pembelajaran konvensional. Penelitian dilakukan dengna menggunakan Pretest-Posttest Control Grup Design.

Penelitian dilakukan di kelas 7A dan 7B SMP Muhammadiyah 2 Depok, Sleman, DIY. Penelitian dilaksanakan antara bulan Januari sampai Maret 2013. Pada jangka waktu tersebut digunakan untuk uji coba instrumen dan pelaksanaan penelitian. Penelitian ini menggunakan strategi pemecahan masalah seba gai variabel bebasnya. Strategi pemecahan masalah adalah suatu strategi pembelajaran yang mengarahkan siswa untuk memecahkan masalah tertentu yang terkait dengan materi pelajaran. Masalah yang digunakan untuk pembelajaran disajikan dalam bentuk studi kasus. Untuk variabel terikat dalam penelitian ini antara lain:

Kemandirian adalah suatu sikap yang menunjukkan kemampuan diri sendiri untuk memahami, menjelaskan dan menganalisis suatu studi kasus yang berisi tentang topik permasalahan di lingkungan sekitar yang terkait dengan materi pelajaran IPS. Kemandirian menunjukkan sikap siswa untuk bersedia mengerjakan sesuatu dengan sen diri dan tidak terlalu bergantung pada orang lain.

Kepedulian adalah suatu sikap yang menunjukkan kepekaan, perhatian dan pemberian solusi terhadap permasalahan yang terjadi di lingkungan sekitar dan terkait deng an materi pelajaran IPS. Kepedulian menunjukkan sikap siswa untuk memperhatikan kondisi orang lain, merasa simpati dan empati serta berusaha untuk membantu dalam setiap kesulitan.

Hasil belajar kognitif adalah hasil pembelajaran yang mengukur pengetahuan dan pemahaman peserta didik terhadap materi pelajaran IPS.

Teknik pengumpulan data menggunakan tes dan non tes. Untuk instrumen pengumpulan data menggunakan instrumen tes hasil belajar kognitif, angket dan pedoman dokumentasi.
Dalam penelitian ini, penentuan validitas terdiri dari validitas rasional dan validitas empiris. Validitas rasional mengacu pada pendapat ahli (expert judgment), sedangkan validitas empiris untuk instrumen tes hasil belajar menggunakan program ITEMAN version 3. 00, untuk intrumen angket menggunakan program SPSS 16. 00 for windows menggunakan nilai r hasil Corrected ItemTotal Correlation melalui menu Scale pada Reliability Analysis. Nilai $\mathrm{r}_{\text {tabel }}$ pada taraf kepercayaan $95 \%$ atau signifikansi $5 \%$ ( $\mathrm{p}=$ 0,05 ) dapat diperoleh melalui df (degree of freedom) dengan menjumlahkan jumlah res ponden $(\mathrm{N})$ dengan jumlah butir pernyataan (k). Dengan demikian pertanyaan dikatakan valid jika nilai $r_{\text {tabel }}$ yang merupakan nilai dari Corrected Item-Total Correlation $>\mathrm{r}_{\text {tabel. }}$

Uji reliabilitas dilakukan dengan menggunakan formula alfa dari Cronbach dengan bantuan komputer yang menggunakan program SPSS 16. 0 for Windows, yaitu apabila koefisien $\alpha>0,7$ maka butir instrumen dianggap reliabel.

Penelitian ini menggunakan teknik analisis yaitu statistik deskriptif dan MANOVA. Statistik deskriptif digunakan untuk menyajikan data dalam bentuk tabel (distribusi frekuensi, ukuran pemusatan, ukuran letak, ukuran keragaman) gambar diagram maupun grafik sehingga mudah dipahami. MANOVA digunakan untuk menentukan apakah terdapat perbedaan signifikan secara statistik pada beberapa variabel yang terjadi secara serentak antara dua tingkatan dalam satu variabel. Untuk menguji perbedaan antar grup pada MANOVA, dilakukan dengan dua uji secara bersama-sama dan uji per variabel.

Uji perbedaan secara bersama-sama (multivariate significant tes) dilakukan de ngan Pillai's Trace, Wilks' Lambda, Hotteling's Trace, dan Roy's Largest Root. Uji per variabel menggunakan Tests of Between-Subject Effects.

\section{HASIL DAN PEMBAHASAN}

\section{Deskripsi Hasil Penelitian}

Dalam penelitian ini terdapat beberapa data, yaitu data pre-test dan post-test hasil 
belajar, kemandirian dan kepedulian baik pada kelompok eksperimen maupun pada kelompok kontrol. Data hasil belajar baik pada kelompok eksperimen maupun kontrol diperoleh dari pelaksanaan pre-test dan post-test materi IPS. Data kemandirian dan kepedulian diperoleh dari penyebaran ins trumen skala sikap pada saat pelaksanaan pre-test dan post-test di kedua kelompok tersebut.

Gambar 1.

Grafik Mean Pre-Test Kelompok Eksperimen dan Kontrol

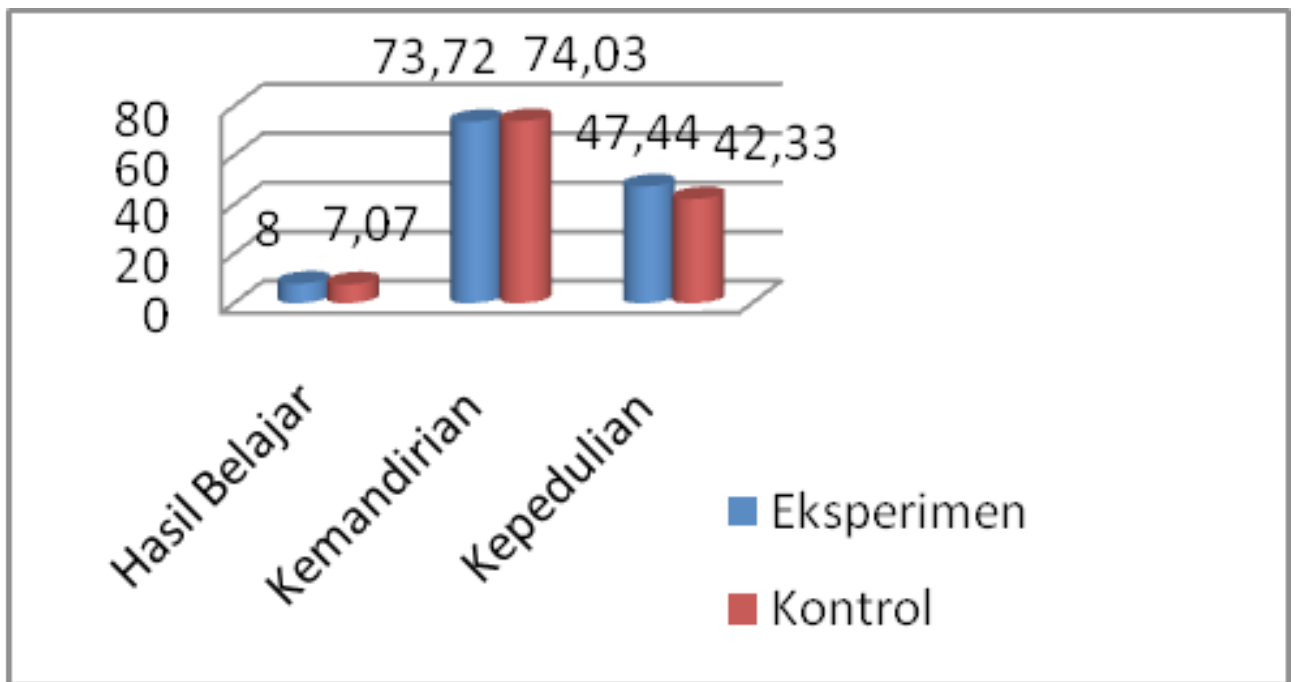

Pada hasil belajar, kelompok eksperimen menunjukkan nilai rata-rata lebih tinggi daripada kelompok kontrol. Akan tetapi perbedaan nilai rata-rata antara kelompok ekspe rimen dan kontrol tidak terlalu jauh yaitu 8 dan 7,07. Hal ini menunjukkan bahwa secara kemampuan kognitif pada mata pelajaran IPS antara kelompok kontrol dan eksperimen tidak menunjukkan perbedaan yang cukup jauh. Secara umum, siswa dapat dikatakan sudah mampu menerima pembelajaran IPS dengan baik karena selama ini hasil pembelajaran IPS sudah mencapai KKM (Kriteria Ketuntasan Minimal).

Hasil data awal (pre-test) dari nilai kemandirian antara kelompok kontrol dan kelompok eksperimen menunjukkan perbedaan rata-rata (mean). Akan tetapi pada data awal, kemandirian untuk kelompok kontrol lebih tinggi dibandingkan dengan kelompok eksperimen. Hal ini membuktikan bahwa selama ini kondisi karakter mandiri siswa lebih baik untuk kelompok kontrol yaitu kelas 7A dibandingkan dengan kelompok eksperimen yaitu kelas 7B. Akan tetapi dengan nilai mean yang ditunjukkan pada data awal (pre-test) menunjukkan bahwa selama ini iklim pembelajaran IPS mampu menghasilkan nilai karakter pada siswa pada kelas 7 .

Hasil data awal (pre-test) dari nilai kepedulian menunjukkan perbedaan ratarata (mean) antara kelompok kontrol dan kelompok eksperimen. Untuk nilai kepedulian menunjukkan bahwa kelompok eksperimen yaitu kelas 7B memiliki nilai mean lebih tinggi dibandingkan dengan kelompok kontrol yaitu kelas 7A. Hal ini menunjukkan bahwa selama ini iklim pembelajaran IPS mampu menghasilkan karakter peduli dian- 
tara siswa-siswa pada kelas 7.

\section{Gambar 2. \\ Grafik Mean Post-Test Kelompok Eksperimen dan Kontrol}

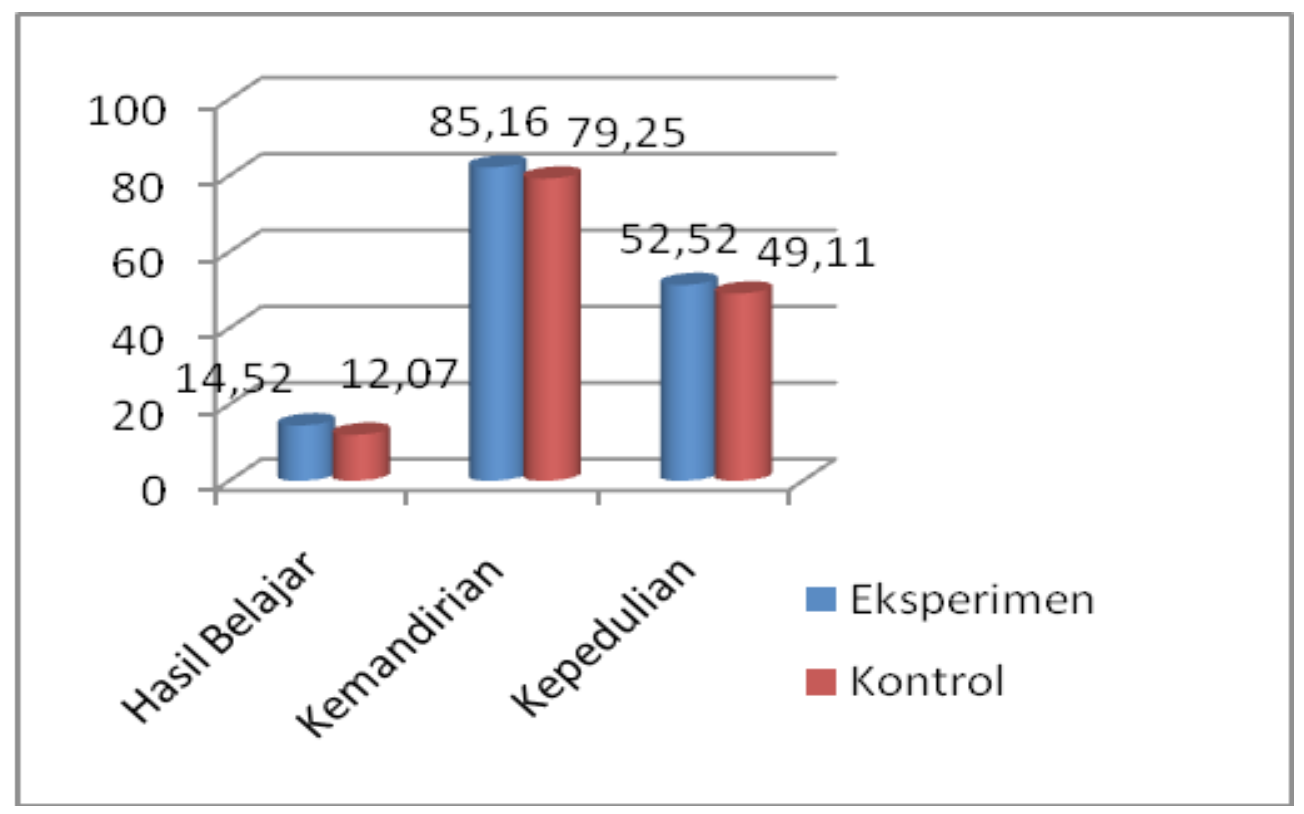

Berdasarkan gambar tersebut dapat dipahamai bahwa data akhir (post-test) menunjukkan perbedaan rata-rata (mean) diantara hasil belajar, nilai kemandirian dan nilai kepedulian pada kelompok kontrol dan eksperimen. Pada hasil belajar, kelompok eksperimen menunjukkan nilai rata-rata lebih tinggi daripada kelompok kontrol. Perbedaan nilai mean hasil belajar cukup tinggi yaitu untuk kelompok eksperimen sebesar 14,52 dan kelompok kontrol sebesar 12,07. Hal ini menunjukkan bahwa secara kemampuan kognitif pada mata pelajaran IPS antara kelompok kontrol dan eksperimen menunjukkan perbedaan yang cukup tinggi dikarenakan perbedaan strategi pembelajaran yang digunakan antar dua kelompok tersebut.

Kelas 7B merupakan kelompok eksperimen menggunakan strategi pemecahan masalah dalam pelaksanaan materi kondisi geografis Indonesia, atmosfer, hidrosfer, Badan Usaha Ekonomi dan Kreativitas Ekonomi. Kelas 7A merupakan kelompok kon- trol yang menggunakan strategi pembelajaran konvensional yang biasa digunakan oleh guru di sekolah tersebut, yaitu ceramah dan diskusi. Strategi pemecahan masalah yang diterapkan pada kelas 7B menjadikan pembelajaran lebih interaktif dan mendalam. Mata pelajaran IPS berisi materi yang sangat dekat dengan fenomena masyarakat yang diamati dan dialami oleh siswa masing-masing. Dengan strategi pemecahan masalah (problem solving) siswa dituntut secara otomatis untuk memahami materi IPS karena akan digunakan dalam memecahkan masalah yang sedang dikerjakan baik secara individu atau kelompok.

Nilai karakter mandiri, antara kelompok eksperimen dan kelompok kontrol memiliki perbedaan mean yang cukup tinggi yaitu 85,16 dan 79,25. Kelas 7B yaitu kelompok eksperimen yang menggunakan strategi pemecahan masalah memiliki nilai karakter mandiri lebih tinggi dengan kelas 7A yaitu kelompok kontrol yang menggunakan strategi pembelajaran ceramah dan diskusi. Strate- 
gi pemecahan masalah menjadikan pembelajaran IPS lebih mengarahkan siswa untuk bekerja dengan kemampuan masing-masing dan mengeksplorasi apa yang menjadi pengetahuannya. Hal ini menjadikan siswa tidak terlaly bergantung dengan materi yang di sampaikan oleh guru seperti yang selama ini dilaksanakan dalam pembelajaran IPS.

Nilai karakter peduli, antara kelompok eksperimen dan kelompok kontrol memili perbedaan nilai rata-rata (mean) yang cukup tinggi yaitu 52,52 dan 49,11. Kelas 7B yaitu kelompok eksperimen yang menggunakan strategi pemecahan masalah memiliki nilai peduli lebih tinggi dengan kelas 7A yaitu kelompok kontrol yang menggunakan strategi pembelajaran ceramah dan diskusi. Strategi pemecahan masalah menjadikan siswa menjadi lebih peka terhadap kondisi di sekitarnya. Hal ini dikarenakan, siswa secara mandiri menemukan masalah yang terjadi dan mencari penyebab serta solusinya.

Mata pelajaran IPS bertujuan untuk menjadikan siswa memahami dan peduli terhadap fenomena sosial yang terjadi, sehingga mereka menjadi manusia sosial yang utuh. Dengan strategi pemecahan masalah, maka dapat dijadikan sebagai cara untuk mencapai tujuan tersebut dan menjadikan pembelajaran IPS menjadi bermakna.

\section{Uji Normalitas}

Uji normalitas dilakukan untuk menguji asumsi bahwa distribusi data membentuk distribusi normal baik pada kelompok eksperimen maupun kelompok kontrol. Perhitungan uji normalitas dilakukan dengan menggunakan uji normalitas metode Kolmogorov-Smirnov dengan fasilitas program SPSS 16.00 for Windows. Hipotesis yang diajukan untuk mengukur normalitas ini adalah sebagai berikut:

Ho $=$ Data berdistribusi normal

$\mathrm{Ha}=$ Data tidak berdistribusi normal

Adapun kriteria pengujian yang dilakukan untuk mengukur normalitas populasi dalam penelitian ini adalah Ho diterima apabila nilai Asymp. Sig (2-tailed)> tingkah alpha yang ditetapkan yaitu 5\%. Tabel 10 berikut menyajikan rangkuman hasil uji normalitas pada kelompok eksperimen maupun kelompok kontrol dengan metode KolmogorovSmirnov menggunakan program SPSS 16. 00 for Windows.

Tabel 11.

Rangkuman Uji Normalitas Kelompok Eksperimen dan Kelompok Kontrol

\begin{tabular}{|c|c|c|c|c|c|c|}
\hline \multirow{4}{*}{ Var } & \multicolumn{4}{|c|}{ Signifikansi Kolmogorov-Smirnov } & \multirow{4}{*}{$\begin{array}{c}\text { Asymp. } \\
\text { Sig. (2-tailed) }\end{array}$} & \multirow{4}{*}{ Ket } \\
\hline & & Kelom & k Data & & & \\
\hline & \multicolumn{2}{|c|}{ Eksperimen } & \multicolumn{2}{|c|}{ Kontrol } & & \\
\hline & Pre-Test & Post-Test & Pre-Test & Post-Test & & \\
\hline Hasil Belajar & 0,271 & 0,664 & 0,122 & 0,463 & Sig $>0,05$ & Normal \\
\hline Kemandirian & 0,927 & 0,514 & 0,502 & 0,683 & Sig $>0,05$ & Normal \\
\hline Kepedulian & 0,743 & 0,235 & 0,671 & 0,203 & Sig $>0,05$ & Normal \\
\hline
\end{tabular}

Berdasarkan tabel 1 tersebut, terlihat bahwa Asymp. Sig. (2-tailed) pre-test dan post-test hasil belajar, kemandirian dan kepedulian pada kelompok eksperimen maupun kontrol mempunyai nilai signifikansi lebih besar dari nilai alpha yang ditetapkan yaitu 5\% $(0,05)$, sehingga Ho diterima. De ngan demikian, dapat disimpulkan bahwa ketiga variabel penelitian membentuk distribusi normal.

\section{Uji Homogenitas}

Uji homogenitas digunakan untuk menentukan tingkat homogen variabel dependen yaitu hasil belajar, kemandirian dan 
kepedulian. Perhitungan uji homogenitas dilakukan dengan menguji asumsi varian dan kovarians dari MANOVA. Pengujian varians dan kovarian dilihat dari dua sisi yaitu diuji secara bersama-sama dan diuji per variabel dependen. Pengujian secara bersama-sama dengan menggunakan Box's M pada MANOVA sedangnya pengujian per variabel dependen dengan menggunakan Levene's Test of Equality of Error Variances.

Pengujian varians dan kovarians secara bersama-sama dengan menggunakan Box's $M$ pada MANOVA hipotesis yang diajukan sebagai berikut:

Ho = Ketiga variabel dependen (hasil belajar, kemandirian dan kepedulian) mempunyai matrik varians dan kovarians yang sama pada kelompok strategi problem solving (pemecahan) masalah dan kelompok strategi pembelajaran konvensional.

$\mathrm{Ha}=$ Ketiga variabel dependen (hasil belajar, kemandirian dan kepedulian) mempunyai matrik varians dan kovarians yang berbeda pada kelompok strategi problem solving (pemecahan) masalah dan kelompok strategi pembelajaran konvensional.

Adapun kriteria pengujian yang digunakan untuk menentukan homogenitas va rian dalam penelitian ini adalah Ho diterima apabila nilai sig $>0,05$, kemudian Ho ditolak apabila nilai sig $<0,05$. Nilai signifikansi pada hasil pengujian Box's $M$ pada MANOVA adalah sebesar 0,690. Dengan demikian nilai siginifikansi lebih besar dari 0,05 sehingga Ho diterima. Pada pengujian Box's $M$ pada MANOVA untuk variabel dependen yaitu hasil belajar, kemandirian dan kepedulian adalah memiliki varian-kovarian yang sama pada kelompok eksperimen yaitu kelompok yang menggunakan strategi pembelajaran problem solving (pemecahan masalah) dan kelompok kontrol yaitu kelompok yang menggunakan strategi pembelajaran konvensional.

Adapun kriteria pengujian yang diguna kan untuk menentukan homogenitas per variabel dalam penelitian ini adalah Ho diterima apabila nilai sig $>0,05$, kemudian Ho ditolak apabila nilai sig $<0,05$. Berikut merupakan rangkuman hasil pengujian homegenitas per variabel dengan Test of Equality of Error Variances pada MANOVA.

Tabel 2

\section{Rangkuman Uji Test of Equality of Error Variances Kelompok Eksperimen} dan Kelompok Kontrol

\begin{tabular}{ccccc}
\hline Variabel & F & Sig & $\begin{array}{c}\text { Sig } \\
\text { (2-tailed) }\end{array}$ & Ket \\
\hline Hasil Belajar & 3,589 & 0,064 & Sig $>0,05$ & Homogen \\
Kemandirian & 1,161 & 0,286 & Sig $>0,05$ & Homogen \\
Kepedulian & 1,317 & 0,257 & Sig $>0,05$ & Homogen \\
\hline
\end{tabular}

Berdasarkan tabel 11 variabel hasil belajar memiliki matrik varian-kovarian yang sama pada kelompok eksperimen dan kontrol. Variabel kemandirian memiliki variankovarian yang sama pada kelompok eksperimen dan kontrol. Selain itu, variabel kepedulian juga memiliki varian-kovarian yang sama pada kelompok eksperimen dan kontrol.

\section{Uji Hipotesis}

Pengujian hipotesis dalam penelitian ini menggunakan teknik analisis MANOVA yaitu untuk mengetahui perbedaan strategi pembelajaran problem solving (pemecahan masalah) dengan strategi pembelajaran konvensional terhadap hasil belajar, kemandirian dan kepedulian.

Adapun hipotesis yang diuji adalah: 
(a) Ho = Strategi pembelajaran problem solving (pemecahan masalah) dan strategi pembelajaran konvensional tidak menunjukkan perbedaan terhadap hasil belajar, nilai kemandirian dan kepedulian secara bersama-sama. Ha = Strategi pembelajaran problem solving (pemecahan masalah) dan strategi pembelajaran konvensional secara bersama-sama menunjukkan perbedaan terhadap hasil belajar, nilai kemandirian dan kepedulian.

(b) $\mathrm{Ho}=$ Strategi pembelajaran problem solving (pemecahan masalah) dan strategi pembelajaran konvensional tidak menunjukkan perbedaan terhadap hasil belajar. $\mathrm{Ha}=$ Strategi pembelajaran problem solving (pemecahan masalah) dan strategi pembelajaran konvensional menunjukkan perbedaan terhadap hasil belajar.

(c) $\mathrm{Ho}=$ Strategi pembelajaran problem solving (pemecahan masalah) dan strategi pembelajaran konvensional tidak menunjukkan perbedaan terhadap nilai kemandirian. $\mathrm{Ha}=$ Strategi pembelajaran problem solving (pemecahan masalah) dan strategi pembelajaran konvensional menunjukkan perbedaan terhadap nilai kemandirian.

(d) Ho = Strategi pembelajaran problem sol ving (pemecahan masalah) dan strategi pembelajaran konvensional tidak menunjukkan perbedaan terhadap nilai kepedulian. $\mathrm{Ha}=$ Strategi pembelajaran problem solving (pemecahan masalah) dan strategi pembelajaran konvensional menunjukkan perbedaan terhadap nilai kepedulian.

Berdasarkan hasil perhitungan diperoleh nilai Pillai's trace, Wilkss' Lambda, Hotteling's Trace dan Roy's Largest Root pada MANOVA sebesar 0,000 yaitu kurang dari 0,05 sehingga Ho ditolak. Berdasarkan perhitungan tersebut maka dapat diambil kesimpulan bahwa strategi pembelajaran problem solving (pemecahan masalah) dan strategi pembelajaran konvensional menunjukkan perbedaan terhadap hasil belajar, nilai kemandirian dan kepedulian secara bersama-sama.

Hasil perhitungan Tests of Between-

Subject Effects pada MANOVA dapat dilihat sebagai berikut:

Tabel 3.

Rangkuman Uji Tests of Between-Subject Effects

\begin{tabular}{cccc}
\hline Source & Dependent Variabel & F & Sig \\
\hline Kelas & Hasil Belajar & 5,602 & 0,029 \\
& Kemandirian & 38,502 & 0,000 \\
& Kepedulian & 12,666 & 0,001 \\
\hline
\end{tabular}

Tabel 3 menunjukkan bahwa nilai signifikani variabel hasil belajar bernilai kurang dari 0,05 yaitu sebesar 0,029 sehingga pene rapan strategi pembelajaran problem solving (pemecahan masalah) dan strategi pembelajaran konvensional menunjukkan perbedaan terhadap hasil belajar. Nilai signifikani variabel kemandirian bernilai kurang dari 0,05 yaitu sebesar 0,000 sehingga penerapan strategi pembelajaran problem solving (peme cahan masalah) dan strategi pembelajaran konvensional menunjukkan perbedaan terhadap nilai kemandirian.

Berdasarkan hasil uji Tests of BetweenSubject Effects pada tabel 3 menunjukkan bahwa nilai signifikani variabel kepedulian bernilai kurang dari 0,05 yaitu sebesar 0,001 sehingga penerapan strategi pembelajaran problem solving (pemecahan masalah) dan strategi pembelajaran konvensional menunjukkan perbedaan terhadap kepedulian.

Berdasarkan hasil penelitian dianalisis 
dengan statistik deskriptif dan Multivariate Analysis of Variance (MANOVA) pada kelompok eksperimen dan kelompok kontrol menunjukkan bahwa strategi pemecahan masalah (problem solving) mampu meningkatkan pendidikan karakter yang terintegrasi dalam pembelajaran IPS. Penelitian ini me ngambil data awal yaitu pre-test baik pada kelompok eksperimen dan kelompok kontrol. Data pre-test digunakan sebagai pembanding data post-test dimana akan terlihat seberapa besar perbedaan antara sebelum dan sesudah dilakukan tindakan pada kelompok masing-masing.

Berdasarkan analisis statistik deskriptif pada data awal (pre-test), siswa kelompok eksperimen sudah menunjukkan hasil yang lebih tinggi daripada kelompok kontrol baik dari hasil belajar dan kepedulian, akan tetapi pada variabel kemandirian kelompok kontrol memiliki rerata yang lebih tinggi dibandingkan dengan kelompok eksperimen.

Hal ini menunjukkan bahwa pada kondisi sebelum dilakukan penerapan strategi pembelajaran problem solving (pemecahan masalah) dari aspek kemandirian pada siswa kelompok kontrol yaitu kelas 7A menunjukkan lebih baik dibandingkan dengan kelompok eksperimen yaitu kelas 7B. Dengan demikian, siswa kelas 7A sudah menyadari bahwa karakter mandiri memang harus dimiliki dan diterapkan dalam kehidupan sehari-hari. Hal ini didukung dengan budaya sekolah dan iklim pembelajaran yang mengarahkan siswa untuk mampu melakukan tugas dan kewajibannya sendiri tanpa selalu melibatkan orang lain.

Misalnya mengerjakan tugas dari guru tanpa menyontek siswa lain karena sistem penugasan secara individu mendominasi pada pembelajaran IPS di SMP Muhammadiyah 2 Depok, Sleman. Selain itu, kegiatan sekolah yang mengarahkan pada kemandirian adalah Hizbul Wathon (kepanduan) dimana siswa melakukan kegiatan perkemahan yang mengarahkan siswa untuk melakukan tugas dan kewajibannya sendiri tanpa sepenuhnya dibantu oleh guru atau orang tua. Dalam kegiatan keagamaan, siswa mendapat tugas untuk menjadi mempimpin tadarus, menjadi imam ataupun khotib dalam sholat berjamaah. Tugas tersebut dilaksanakan oleh siswa dengan baik karena guru tidak sepenuhya terlibat akan tetapi hanya memberikan pengarahan saja. Selain data awal (pre-test) untuk variabel kemandirian yang sudah dijabarkan tersebut, maka selanjutnya adalah untuk data awal (pre-test) pada variabel kepedulian dan hasil belajar menunjukkan bahwa siswa kelompok eksperimen lebih baik dibandingkan dengan kelas kontrol.

Hal ini menunjukkan bahwa karakter kepedulian sudah dimiliki dan diterapkan secara baik oleh siswa pada kelompok eksperimen yaitu kelas 7B. Karakter kepedulian dikembangkan melalui budaya sekolah de ngan pendekatan keteladanan. Pada sekolah tersebut terdapat salah satu program yang menunjukkan rasa kepedulian antar warga sekolah yaitu "Jumat Peduli". Jumat peduli merupakan kegiatan sedekah secara sukarela baik dari guru dan siswa yang bertujuan untuk membantu sesama warga sekolah yang sedang mengalami musibah. Guru memberikan teladan dengan menunjukkan secara langsung bahwa guru terlibat menjadi salah satu pemberi sedekah tersebut, sehingga ini diikuti oleh semua siswa.

Berdasarkan analisis statistik deskriptif pada data akhir (post-test), siswa kelompok eksperimen menunjukkan hasil yang lebih tinggi daripada kelompok kontrol baik dari nilai kemandirian, kepedulian dan hasil belajar. Rerata kelompok eksperimen lebih tinggi dibandingkan dengan kelompok kontrol.

Kelompok eksperimen menggunakan strategi pembelajaran problem solving (pemecahan masalah) dalam materi mata pelajaran IPS. Selain itu, berdasarkan hasil uji MANOVA menunjukkan bahwa terdapat perbedaan baik secara bersama-sama maupun per-variabel untuk kemandirian, kepedulian dan hasil belajar pada kelompok eksperimen dan kelompok kontrol. Variabel kemandirian, kepedulian dan hasil belajar menunjukkan hasil yang signifikan sehingga strategi pembelajaran problem solving (pemecahan masalah) efektif untuk meningkatkan kemandirian, kepedulian dan hasil belajar siswa. 
Strategi pembelajaran problem solving (pemecahan masalah) mengarahkan siswa untuk aktif dalam memecahkan topik masalah yang terkait dengan materi yang sedang diajarkan. Siswa menjadi bersema ngat dengan pembelajaran kelompok yaitu diskusi dan presentasi. Selain itu, strategi pembelajaran problem solving (pemecahan masalah) mengarahkan siswa untuk mampu menyelesaikan tugas yang diberikan dengan kemampuan sendiri tanpa selalu diberikan materi oleh guru. Siswa berusaha sendiri memahami materi yang dipelajari dengan diberikan topik permasalahan yang berkaitan dengan materi dan ada di lingkungan sekitar siswa. Strategi pembelajaran problem solving (pemecahan masalah) menjadikan siswa peka terhadap lingkungan sekitar yang dan fenomena yang terjadi. Hal ini menuntut adanya nilai kepedulian yang harus dimiliki oleh siswa karena topik masalah yang diberikan dapat dipecahkan dan diberikan solusi jika siswa tersebut memahami objek yang menjadi topik permasalahan. Selain itu, siswa diarahkan untuk berpikir sendiri secara lebih luas sehingga analisis dan solusi yang diberikan mampu menjawab masalah yang sedang dibahas tersebut.

Keberhasilan penelitian ini tidak terlepas dari pola pendidikan dan pengajaran yang diterapkan selama ini oleh SMP Muhammadiyah 2 Depok, Sleman. Salah satunya adalah budaya sekolah yang merupakan cermin dari karakteristik sekolah tersebut sehingga membedakan dengan sekolah yang lain. Budaya sekolah yang sudah dijalankan oleh SMP Muhammadiyah 2 Depok, Sleman mengarahkan siswa untuk memiliki nilai kemandirian yang tercermin dalam kesadaran masing-masing siswa untuk melaksanakan tugas baik dalam kegiatan intrakurikuler maupun eksrakurikuler. Selain itu, kegiatan rutin sekolah yang melibatkan siswa seperti: tadarus, sholat dhuha dan zuhur berjamaah menuntut siswa untuk secara sadar menjalankan rutinitas tersebut. Dalam proses belajar, siswa diarahkan untuk menyadari tugas masing-masing baik yang berhubungan dengan mata pelajaran, guru dan antar siswa itu sendiri. Guru tidak pernah berhenti untuk memberikan pemahaman moral dan akhlaq kepada siswa di Sekolah tersebut. Hal tersebut dilakukan setiap kegiatan mengajar dan di luar kegiatan mengajar.

Di luar kegiatan mengajar, sekolah memiliki beberapa kegiatan yang menunjuang pembentukan karakter seperti: khotbah setelah sholat dzuhur berjamaah, kajian kelompok keputrian, bersih sekolahku, kelompok pembinaan, outdoor learning, bakti sosial, pengajian dan pertemuan rutin guru dengan orang tua wali serta kegiatan ekstra kurikuler lainnya. Selain itu ada program pembinaan psikologi dari seorang psikolog untuk siswa kelas 7, 8, dan 9 yang bertujuan untuk memberikan semangat dan motivasi belajar siswa serta membina sikap siswa agar menjadi pribadi yang baik. Selain pembinaan psikologi untuk siswa, juga dilakukan diskusi dan pengarahan pola pendidikan untuk anak dari seorang psikolog kepada orang tua wali. Hal ini menunjukkan bahwa pendidikan karakter di SMP Muhammadiyah 2 Depok, Sleman sudah melibatkan peran orang tua selain peran guru dan kepemimpinan sekolah. Berdasarkan uraian diatas maka penelitian dengan judul "Keefektifan Pembelajaran IPS dengan Strategi Pemecahan Masalah untuk Meningkatkan Kemandirian dan Kepedulian Siswa" membuktikan bahwa strategi peme cahan masalah efektif untuk meningkatkan hasil belajar dan nilai nilai karakter terutama kemandirian dan kepedulian dalam pembelajaran IPS.

Hasil penelitian menunjukkan terjadi peningkatan rerata untuk nilai kemandirian, kepedulian, dan hasil belajar dari sebelum diterapkan strategi pembelajaran problem solving (pemecahan masalah) dan setelah diterapkan strategi pembelajaran problem solving (pemecahan masalah).

Strategi belajar mengajar problem solving memberi tekanan pada terselesaikannya suatu masalah secara menalar. Pentingnya strategi belajar mengajar ini karena pada prinsipnya adalah suatu proses interaksi antara manusia dan lingkungannya. Proses ini dapat juga disebut sebagai proses internalisasi, karena ada interaksi manusia yang secara aktif mengamati, memahami dan 
menganalisis permasalahan di lingkungan sekitarnya.

Penelitian ini membuktikan bahwa strategi pembelajaran problem solving (peme cahan masalah) efektif untuk meningkatkan karakter kepedulian. Hasil ini selaras dengan yang diutarakan oleh Wina Sanjaya (2008: 220) yaitu salah satu keunggulan dari strategi pemecahan masalah adalah dapat membantu siswa bagaimana mentransfer penge tahuan dan memahami kehidupan nyata. Secara keseluruhan, strategi pembelajaran problem solving (pemecahan masalah) telah berhasil meningkatkan hasil belajar, nilai kemandirian dan kepedulian siswa dalam iklim pembelajaran IPS. Mata pelajaran IPS dibuktikan mampu menjadi wahana pembelajaran untuk menumbuhkan nilai-nilai karakter yang seyogyanya dimiliki dan diterapkan dalam kehidupan sehari-hari oleh siswa.

Strategi pembelajaran dapat bervariasi yang termasuk dalam inkulkasi nilai, keteladanan, fasilitas nilai, dan pengembangan softskill. Metode inkulkasi nilai dilakukan dengan penyampaian keyakinan dengan diberi alasan, pengontrolan kondisi lingkungan, memberi peluang bagi munculnya perilaku yang berbeda, dan memberikan kesempatan untuk memperbaiki diri. Ketelada nan diberikan berupa contoh perbuatan (dan kata-kata) yang dapat ditiru oleh siswa. Untuk fasilitas nilai diberikan dengan pemberikan kesempatan kepada subjek didik untuk meningkatkan hubungan dengan pendidik, mendengarkan pendidik dengan baik, menyusun pendapat dan memperjelas hal-hal yang masih meragukan. Dalam hasil penelitian tersebut disebutkan bahwa dengan strategi pembelajaran yang mengembangkan softskill mampu menumbuhkan nilai-nilai karakter siswa. Kemampuan dalam meme cahkan masalah yang ada dalam kehidupan sehari-hari merupakan wujud dari softskill pada siswa dan terbukti mampu meningkatkan nilai karakter mandiri dan peduli.

\section{SIMPULAN}

Berdasarkan analisis data dan pembahasan, maka penelitian ini dapat disimpulkan sebagai berikut: 1) Strategi pembelajaran pemecahan masalah dan strategi pembelajaran konvensional menunjukkan perbedaan terhadap hasil belajar, nilai kemandirian dan kepedulian secara bersama-sama. 2) Penerapan strategi pembelajaran pemecahan masalah dan strategi pembelajaran konvensio nal menunjukkan perbedaan terhadap hasil belajar. 3) Penerapan strategi pembelajaran pemecahan masalah dan strategi pembelajaran konvensional menunjukkan perbedaan terhadap nilai kemandirian. 4) Penerapan strategi pembelajaran pemecahan masalah dan strategi pembelajaran konvensional menunjukkan perbedaan terhadap kepedulian.

\section{UCAPAN TERIMA KASIH}

Kami ucapkan terima kasih kepada semua pihak yang telah membantu terselesaikannya penelitian ini. Selain itu terima kasih kepada redaksi yang telah memuat artikel penelitian ini sehingga hasil penelitian dapat dibaca secara luas.

\section{DAFTAR PUSTAKA}

Muhson, Ali, dkk. 2008. Peningkatan Minat Belajar dan Pemahaman Mahasiswa Melalui Pembelajaran Problem Solving. Jurnal Social Vol V No. 1 Mei 2008.

Badan Penelitian dan Pengembangan, Pusat Kurikulum. 2011. Pengembangan Pendidikan Budaya Dan Karakter Bangsa Pedoman Sekolah. Jakarta: Kemendiknas.

Badan Standar Nasional Pendidikan 2006. Standar Isi, Standar Kompetensi Dan Kompetensi Dasar Untuk Satuan Pendidikan Dasar Dan Menengah. Jakarta: BSNP.

Depdiknas. 2005. Peraturan Pemerintah RI no. 19 tahun 2005, tentang Standar Nasional Pendidikan.

2006. Peraturan Menteri Pendidikan Nasional no. 24 tahun 2006, tentang Standar Isi untuk Satuan Pendidikan Dasar dan Menengah.

Nasution. 2006. Kurikulum dan Pengajaran. Jakarta : Bumi Aksara.

Raka, Gede dkk. 2011. Pendidikan Karakter di 
Sekolah. Jakarta: Kompas Gramedia.

Sanjaya, Wina. 2008. Strategi Pembelajaran Berorientasi Standar Proses Pendidikan. Jakarta : Prenada.

S. G. , Isaksen dkk. 2011. Creative Approach to Problem Solving. Thousand Oaks: Sage Publication, Inc.

Zuchdi, Darmiyati, dkk. 2011. Pengembangan Model Pendidikan Karakter dengan Pendekatan Komprehensif Terpadu dalam Pembelajaran Bahasa Indonesia, IPA dan IPS Di Sekolah Dasar. Laporan Penelitian Hibah Penelitian TIM Pascasarjana-HPTP (Hibah Pasca). Yogyakarta: Program Pascasarjana Universitas Negeri Yogyakarta.
2010. Humanisasi Pendidikan. Jakarta: Bumi Aksara.

2011. Pendidikan Karakter: Dalam Perspektif Teori dan Praktik. Yogyakarta: UNY Press. (Editor).

2011. Implementasi Pendidikan Karakter Di Perguruan Tinggi. Makalah yang disajikan dalam Seminar Nasional di FISE UNY. 